\title{
NEW BIRD RECORDS AND SOME NOTES FOR THE VIRGIN ISLANDS
}

\author{
By Harry A. Beatty
}

Christiansted, St. Croix, V. I., U. S. A.

This paper is an account of observations and collections I made on St. Croix, St. Thomas, St. John, Tortola, Virgin Gorda and numerous small outlying islands and cays.

In this account I have included species which were previously recorded from the Virgin Islands but are now placed on record for the first time as breeding birds. Among the rare finds was the discovery of a small colony of nesting Blue-faced Booby (S. d. dactylatra).

It seems highly improbable that the Quail-clove, Oreopeleia montana montana, at one time winged its way through the jungles of St. Croix. If that were true then we ought, perhaps, to assume that the species disappeared some time during the short period of sixty years and another form emerged upon the scene and today has become fairly common. My desire to take specimens of montana has spurred me on to find it here since 1918. A search on St. Thomas for montana has likewise been unsuccessful. I looked for it during a total time of six weeks over a three year period on six different trips. Peters, in his Check-list of Birds of the World, Vol. 3, makes no mention of any St. Croix record and indicates that the record for St. Thomas is questionable. However, if it does occur there it must be extremely rare while today $O$. $m$. beattyi is the prevalent form although an extremely shy bird due in greater part, no doubt, to the continuous persecution by gunners. The Quail-dove on St. Croix is an unsuspicious bird not harassed by gunners and well protected by sentiment and legislation.

On Tortola, B. V. I., the Quail-dove is unknown by all its familiar names. The natives will insist that they know only of a "Marmee-dove" in the woods. On March 13, 1941, while on a visit to that island, eight birds came under observation and several specimens were taken. All were of one species. I also learned that the Marmee-dove is very uncommon and greatly restricted in its range. On Virgin Gorda I searched an entire afternoon on April 22nd for the Quail-dove, ever on the alert to catch a song, but nothing was heard nor seen of it. 
Puffinus therminieri therminieri.-Audubon Shearwater. Little Saba Cay : March 10, 1941. Eggs in nest-holes. April 16, 1941. Downy young in nests. A number of adults were taken from nest-holes and prepared as skins, among them were 5 males and 5 females. I cite this species to record the observation that both sexes shared in the incubation. Each bird collected was sitting on an egg. Later, the downy young alone were occupying the nest-holes.

Phaethon aethereus mesonauta.-Red-billed Tropic-bird. Cockroach Cay : Two pairs, nesting in cliffs, were observed first on March 11th and again on April 17, 1941. On Virgin Gorda two pairs were nesting in cliffs west of Gorda Sound, April 22, 1941.

Phaethon lepturus catesbyi- - Yellow-billed Tropic-bird. Little Saba Cay: An immature was taken from its nest on April 16, 1935. Water Island: March 21, 1941, ten pairs were nesting in high cliffs. Dutchmans Cap: July 11, 1940, a pair was seen taking food to a young bird on the rocks. Virgin Gorda, April 22, 1941. Two pairs were nesting in cliffs at Gorda Sound.

Sula dactylatra dactylatra.-Blue-faced Booby. Cockroach Cay: April 17, 1939. . Four adults were seen, one bird occupying an unlined nest containing two eggs. March 30, 1940, I saw eight adults and a nest occupied by one snow white downy young. On July 12, 1940, ten adults were seen; a nest with one egg and another with one big fluffy downy. On March 11, 1941, I saw ten adults and two nests containing two eggs each guarded by adults. Another nest held a very big fluffy nestling with which I played at "pecking" while the parent bird nestled up close and looked on approvingly. One immature was seen on the wing.

Fregata magnificens rothschildi.-Frigate-bird. Little Tobago Cay: March 13, 1940. I visited the cay for data but rough seas made landing impossible. About 200 adults and many white headed immatures were on the wing. Local fishermen tell me that nesting begins about January.

Circus cyaneus hudsonius.-Marsh Hawk. St. Croix: A new record was added to the fauna when fifteen of these hawks were seen on November 2, 1940. Each bird was in the brown phase and several of them could be seen daily until April 16, 1941. A specimen was taken on November 9, 1940, and another on January 15, 1941.

Pandion haliaetus carolinensis.-Osprey. St. Thomas: Mr. Nichols tells me that he had seen two nestlings which he recognized as this species. They had been removed from a nest on the cliffs of an unidentified cay somewhere in the Tortola area. The time was about March in 1940. 
Falco peregrinus peregrinus.-European Duck-hawk. St. Croix: At dusk, November 9, 1940, I collected a Duck-hawk. The specimen was included in a package of skins sent to Dr. Louis B. Bishop. Dr. Bishop has written to tell me that he considers it to be the European Falcon. This is a new record for St. Croix, and for the West Indies.

Oxyechus vociferus rubidus.-Antillean Killdeer. St. Croix: The antillean killdeer was first recorded on September 26, 1939. A pair caring for two downy young was seen on October 28, 1939, and again on February 10, 1941, another pair was found with three downy. This is a first record for the island.

Ereunetes mauri-Western Sandpiper. St. Croix: Several specimens were taken in August and September, 1939. A new record.

Larus atricilla.-Laughing Gull. Flat Cay: June 26, 1940, a colony of 100 adults, 10 nests of three eggs each.

Gelochelidon nilotica. Gull-billed Tern. Cockroach Cay: July 12, 1940, about 50 birds occupied a ridge and I counted ten nests with two downy young in each. The nests were cups in a bed of short grass quite close to a nesting colony of Royal Terns.

Sterna hirundo hirundo.-Common Tern. St. Croix: On September 26 and again on October 15, 1939, a flock of eighteen common terns was encountered on their feeding grounds two miles offshore. I collected two specimens, one of which had been banded on June 9, 1938, at Penikese Island, Massachusetts, by Dr. O. L. Austin. This is a new record.

Sterna dongallii dougallii.-Roseate Tern. St. Thomas: A colony of 200 nested on coastal cliffs at Bivoni Bay and had downy young on June 26, 1939. At Little Saba Cay a colony of 200 was found nesting on the cliffs on July 2, 1940.

Sterna anaethetus melanoptera.-Bridled Tern. Flat Cay and Little Saba Cay: A colony of 200 birds were nesting and downy young and some eggs were noted on June 26, 1940. Each nest contained a single egg placed on bare earth under shrubbery.

Sterna fuscata fuscata.-Sooty Tern. Dove Cay, Flat Cay, Little Saba Cay: A colony of 100 terns was caring for downy young and incubating late eggs on June 26, 1940. The single egg in each nest was resting on bare earth under protective shrubbery.

Thalasseus maximus maximus.-Royal Tern. Cockroach Cay: July 12, 1940. A colony of 40 adults was found caring for downy young having either one or two young in each nest.

Anous stolidus stolidus. - Noddy. The noddy starts nesting early in June. Colonies of from 100 to 500 birds were found nesting on Cock- 
roach, Little Saba, Flat Cay and Ginger Island. The single egg is deposited on the bare rock-ledge, usually in a cliff facing.

Oreopeleia mystacea beattyi,-Quail-dove. St. John: March 13, 1940. Several specimens were collected. This is a new discovery in the fauna of the island. Tortola, B. V. I. : March 15, 1941. Specimens taken also constitute a new discovery for Tortola and will likely prove to be the most easterly limits in the range of beattyi.

Protonotaria citrea.-Prothonotary Warbler. St. Croix: A male was collected on October 6, 1940. Grange Swamp. A new record.

Helmitheros vermivoros.-Worm-eating warbler. St. Croix: On October 31, 1940, two specimens were taken on Mt. Eagle, and another was seen on April 9, 1941. A new record.

Dendroica breviunguis.-Black-poll Warbler. St. Croix: About fifteen of these warblers were observed in an extensive field overgrown with thorny acacia, first on October 23, 1940, and thereafter at intervals for two weeks. Several specimens were taken. A new record.

Dendroica discolor collinsi.-Florida Prairie Warbler. St. Croix: Among a number of warbler skins sent to Dr. Bishop was one specimen which he identified as this form. It was taken on October 24, 1940. A new record.

Wilsonia citrina--Hooded Warbler. St. Croix: A male bird was collected on March 16, 1941. It was flitting amongst undergrowth following a streamway when first observed. This is a new record.

\section{ACKNOWLEDGMENTS}

On all my visits to the islands and cays in the Virgin Islands group the greatest difficulty was transportation. For assistance in making these arrangements and other courtesies it is a pleasure to mention my gratitude to various people.

To The Honorable Robert M. Lovett, Acting Governor of the V. I., U. S. A., for his kindly interest in my plan to continue scientific investigations of local faunas. Mr. M. F. de Castro, Commissioner of Finance, expedited the issuance of collecting permits. Mr. D. Boreham, Superintendent of Public Works, gave material assistance on several occasions. Norman Grigg gave unstintingly of his time and captained his very seaworthy power-boat on several trips, adding greatly to the success of sea bird collecting. Mr. R. Nichols, Director of the Extension Station, also assisted me and his knowledge of local birds was of value. I was very much inpressed by the excellent collection of eggs of Virgin 
Islands birds which $\mathrm{Mr}$. Nichols has brought together. Among them is a set of three eggs of the rare little owl, Otus mudipes newtoni, collected on St. Thomas in May 1936. The eggs are snowy white in color. I shall remember the kindnesses of Dante de la Garde who stands alone in the interest of conservation on that island. He needs cooperation if the ruthless traffic in eggs and, especially, the young of all sea birds and game birds is to be stamped out. Thanks are due Desmond Fabio for his hospitality and much oral information about the cays.

I must mention His Honour D. P. Wailing, Commissioner of Tortola, B. V. I., for his gracious consent in granting permits for collecting on that island and his deep interest in my findings. And Mr. Roy, Director of the Botanical Station, who joined me on several excursions, his knowledge of the island and of the people rendering collecting a simpler task.

Special thanks are due Senor V. Balbas Peña, of San Juan, for an invitation to join a party of friends vacationing among the islands on his motor cruiser "Malola," During the trip there were abundant opportunities for ornithological observations in which I was ably assisted by the enthusiasm and alertness of shipmates Julio Rodriguez and Gtuillermo Margaridas, of San Juan, and Anton C. Teytaud, of St. Croix. 